\title{
QUALITY CHANGES IN FRESH CHIVES (ALLIUM SCHOENOPRASUM L.) DURING REFRIGERATED STORAGE
}

\author{
SONIA Z. VIÑA ${ }^{12.3}$ and ELSA L. CERIMELE ${ }^{2}$ \\ ${ }^{1}$ CIDCA (Centro de Investigación y Desarrollo en Criotecnología de Alimentos) \\ Facultad de Ciencias Exactas \\ Universidad Nacional de La Plata UNLP - CCT La Plata CONICET \\ 47 y $116 \mathrm{~S} / \mathrm{N}^{\circ}$, La Plata (B1900AJJ) \\ Buenos Aires, Argentina \\ ${ }^{2}$ Curso Bioquímica y Fitoquímica \\ Facultad de Ciencias Agrarias y Forestales UNLP \\ 60 y 119 S/N ${ }^{\circ}$, La Plata (1900) \\ Buenos Aires, Argentina
}

Received for Publication November 30, 2007

Accepted for Publication September 6, 2008

\begin{abstract}
This study investigates quality changes in fresh chives stored at 0 and $4 C$ during 21 and 14 days, respectively. The product was packaged in trays and covered with polyvinyl chloride films. Weight loss, surface color, total chlorophyll, carotenoids, reducing sugars and browning potential were evaluated in order to determine shelf life at each temperature. In addition, internal atmosphere composition, total phenolics, radical scavenging activity and ascorbic acid content were measured for samples stored at $0 C$. Results showed that surface color change and losses of green pigments and reducing sugar content could be delayed for a week by storing fresh chives at $0 C$. The increase in browning potential was of lower magnitude at $0 C$ than at $4 C$. High quality levels and marketability of fresh chives could be maintained for 2 weeks at $0 C$.
\end{abstract}

\section{PRACTICAL APPLICATIONS}

The marketing of packaged and refrigerated, value-added culinary herbs is a choice of increasing interest for vegetables processors. However, data on changes in the chemical composition and antioxidative properties of fresh 3 Corresponding author. TEL: 54-221-424-9287; FAX: 54-221-425-4853; EMAIL: soniavia@
quimica.unlp.edu.ar 
herbs during storage are scarce. This study provides information on how quality attributes of fresh chives are affected under different conditions of postharvest handling and storage.

\section{INTRODUCTION}

Chive (Allium schoenoprasum L.) is a Central European spice plant belonging to the Liliaceae family. From an agricultural point of view, chives are morphologically well adapted to dry and sunny habitats because of their tubiform leaves that offer a reduced transpiring surface and their small bulbs, which act as water reservoirs (Egert and Tevini 2002). Chive leaves are traditionally used after being dried or, alternately, are stored frozen. The first procedure considerably reduces the characteristic aroma (Kmiecik and Lisiewska 1999), while freezing often affects texture and color. Therefore, the marketing of value-added fresh chives packaged in plastic trays and stored at refrigeration temperatures is another way of processing of increasing interest.

Several species of the Allium genus such as onion, garlic and leek have been used both in human diet and folk medicine since ancient times (Tsiaganis et al. 2006). The specific organosulfur compounds present in these species have been extensively studied for their chemopreventive potential against cancer (Le Bon and Siess 2000).

Epidemiological studies have shown that a higher intake of Allium products is associated with a reduced risk of several types of cancers (Sengupta et al. 2004). Garlic, onion, leeks and chives have been reported to reduce the incidence of stomach and colorectal cancers. Evidence for a protective effect against malignant neoplastic diseases at other sites, including the breast, is still insufficient, according to Bianchini and Vainio (2001).

Mechanisms proposed to explain the cancer-preventive effects of Allium species include inhibition of mutagenesis, modulation of enzyme activities, inhibition of DNA adducts formation, free-radical scavenging activities and effects on cell proliferation and tumor growth (Sengupta et al. 2004).

In Allium schoenoprasum, Štajner et al. (2004) have found that leaves have the highest antioxidant activity in comparison with bulbs and stalks because of the high activity of enzymes related to the antioxidant system and the high levels of antioxidants (flavonoids, vitamin $\mathrm{C}$ and carotenoids). Nevertheless, despite this extensive body of research, available information on changes in the chemical composition of chives during storage is still scarce (Kmiecik and Lisiewska 1999).

When it comes to presentation, quality characteristics of fresh culinary herbs, such as chives, are largely visual and include appearance of freshness, uniformity of size, form and color and lack of defects (damaged or yellowed 
leaves, decay, insect damage, wilting) (Cantwell and Reid 2006). Characteristic flavor is essential for culinary herbs quality as well. Because essential oils and aroma generally decrease during storage, the formal quantitation of the effects of storage on herb quality is crucial. The objective of this study was to evaluate quality changes in packaged and refrigerated chives. We have focused on fresh chives stored at 0 and $4 \mathrm{C}$ for 21 and 14 days, respectively.

\section{MATERIALS AND METHODS}

\section{Plant Material}

Chive plants (A. schoenoprasum L.) were grown at the Experimental Station "Julio Hirschhorn" of the Universidad Nacional de La Plata Agronomy College (Los Hornos, Buenos Aires, Argentina). Its geographic location is $34^{\circ} 52^{\prime} \mathrm{S}, 57^{\circ} 58^{\prime} \mathrm{W}$, its height above mean sea level is $15 \mathrm{~m}$ and its average annual precipitation is $1,018 \mathrm{~mm}$.

The crop was 2 years old. Row spacing was $0.70 \mathrm{~m}$, and in-row distance was $0.25 \mathrm{~m}$. Plants were grown without supplementary irrigation.

Plants about $30 \mathrm{~cm}$ in height were harvested manually, both in April and in November 2005. The harvested material was brought to the laboratory and processed immediately. Leaves showing evidence of damage or disease symptoms were discarded, and any soil was removed by dry cleaning. Leaves were cut (approximately $20 \mathrm{~cm}$ long) with a sharp, stainless steel knife and placed on plastic trays $(23 \times 11 \times 4 \mathrm{~cm})$ covered with self-adhering polyvinyl chloride film (thickness: $10 \mu \mathrm{m} ; \mathrm{O}_{2}$ permeability: $11,232 \mathrm{~cm}^{3} / \mathrm{m}^{2} / \mathrm{atm} /$ day; $\mathrm{CO}_{2}$ permeability: $48,552 \mathrm{~cm}^{3} / \mathrm{m}^{2} / \mathrm{atm} / \mathrm{day}$; water vapor permeability: $40 \mathrm{~g} / \mathrm{m}^{2} /$ day).

\section{Determinations for Assessing Shelf Life of Fresh Chives Stored at 0 and $4 \mathrm{C}$}

Trays containing approximately $50 \mathrm{~g}$ of product were stored for 3 and 2 weeks at 0 and $4 \mathrm{C}$, respectively. Samples were withdrawn for analysis at 0,7 , 14 and 21 days.

Weight loss of trays was determined with a digital balance $( \pm 0.01 \mathrm{~g})$ at the beginning and end of the storage period. Relative weight loss was calculated with respect to the initial weight, and results were expressed as percentage $(\%)$.

Surface color measurements were carried out by using a Minolta CR 300 colorimeter (Osaka, Japan) with an 8-mm-diameter measuring area. The instrument was calibrated with a standard white plate $(Y=93.2, x=0.3133$, 
$y=0.3192$ ). $L^{*}$ (lightness), $a^{*}$ and $b^{*}$ coordinates of the CIE scale were recorded. Hue angle $\left(h=\tan ^{-1}\left[b^{*} / a^{*}\right]\right)$ was calculated.

For total chlorophyll and carotenoid content analysis, leaves were frozen in liquid $\mathrm{N}_{2}$ and crushed in a laboratory mill (Janke \& Kunkel Ika Labortechnik A10, Staufen, Germany). Samples $(0.5 \mathrm{~g})$ were extracted with $5 \mathrm{~mL}$ of cold acetone. Total chlorophyll and carotenoid content were determined according to Lichtenthaler (1987). Absorbance was measured at 470, 644.8 and $661.6 \mathrm{~nm}$. Final results were expressed as $\mathrm{mg} / 100 \mathrm{~g}$ fresh tissue.

Extraction of soluble sugars was performed on $0.3-0.5 \mathrm{~g}$ of frozen and crushed material, with $7 \mathrm{~mL}$ of ethanol $96 \% \mathrm{wt} / \mathrm{wt}$ at room temperature. The mixture was centrifuged at $11,000 \times \mathrm{g}$ for $10 \mathrm{~min}$. Reducing sugars content was determined spectrophotometrically at $520 \mathrm{~nm}$ by using a modification of the Somogyi-Nelson method (Southgate 1976). Glucose was used as standard. Results were expressed as g glucose $/ 100 \mathrm{~g}$ fresh tissue.

Browning potential was calculated from reading the absorbance at $320 \mathrm{~nm}$ on the extracts performed with ethanol 96\% wt/wt (Loaiza-Velarde et al. 1997). Final results were expressed as absorbance units/g fresh tissue.

\section{Determinations Carried Out in Samples Stored at 0C for 14 Days}

Once the shelf life of the product at the optimal temperature was established, atmosphere composition and antioxidant activity of fresh chives were determined. In this case, samples were withdrawn for analysis at $0,3,6,9$ and 14 days.

The composition of internal atmosphere inside packages was measured with a Shimadzu gas chromatograph model GC-6APTF (Kyoto, Japan) fitted with a thermal conductivity detector. An Alltech CTR1 (Deerfield, IL) column was employed. The carrier gas was helium, at a flow rate of $30 \mathrm{~mL} / \mathrm{min}$. The injector and detector temperatures were both $120 \mathrm{C}$. The column was held at 30C. A calibration curve was constructed based on different $\mathrm{CO}_{2}$ and $\mathrm{O}_{2}$ concentrations. Analysis of the internal atmosphere was performed at $0,1,2$, $3,6,9,13$, and 17 days of storage. Final results were expressed as $\mathrm{mL} / 100 \mathrm{~mL}$.

Total phenolics were quantitated on the ethanolic extracts, employing the Folin-Ciocalteu reagent (Swain and Hillis 1959). Absorbance readings were taken at $760 \mathrm{~nm}$. Catechin was used as standard, and final results were expressed as mg catechin/100 $\mathrm{g}$ fresh tissue.

Ascorbic acid content was determined, with a modified version of the method proposed by Wimalasiri and Wills (1983). Samples were extracted with $5 \mathrm{~mL}$ aqueous solution of $3 \%$ citric acid. A Waters Model 6,000A (Milford, MA) high-performance liquid chromatograph was used. A C18 column was employed (particle diameter: $5 \mu \mathrm{m}$; internal diameter: $4.6 \mathrm{~mm}$; length: $25 \mathrm{~cm})$. The mobile phase was $0.2 \mathrm{M} \mathrm{KH}_{2} \mathrm{PO}_{4}(\mathrm{pH}=2.4)$. Flow rate 
was $1 \mathrm{~mL} / \mathrm{min}$. Detection was carried out with an ultraviolet (UV) detector at $254 \mathrm{~nm}$. For identification and quantitation, a standard ascorbic acid solution was employed. Final results were expressed as mg ascorbic acid/100 $\mathrm{g}$ fresh tissue.

The radical scavenging activity of the ethanolic extracts was determined by reaction with the radical 2,2-diphenyl-1-picrylhydrazyl (DPPH') (BrandWilliams et al. 1995). Concentration of the extracts was varied in the reaction mixtures by adding $0,10,20,40,60,80$ or $100 \mu \mathrm{L}$. of each of them to a $2 \mathrm{~mL}$ of $\mathrm{DPPH}^{\circ}$ in methanol solution ( $25 \mathrm{ppm}$ ), completing a final volume of $2.1 \mathrm{~mL}$ with methanol. The reaction was allowed to progress, and absorbance was measured at $515 \mathrm{~nm}$ after a constant value was reached. Then, $\mathrm{DPPH}^{\cdot}$ was calculated through a calibration straight line obtained in a range of concentrations of this compound. Finally, the remaining DPPH concentration was plotted as a function of the extract volume in the reaction mixture to calculate $\mathrm{EC}_{50}$ (effective mean concentration) for each sampling point. Final results were expressed as $\mu \mathrm{mol} \mathrm{DPPH}^{*} / 100 \mathrm{~g}$ fresh tissue.

\section{Statistical Analysis}

Two replications of the experiments were performed. Each determination was carried out at least twice. Results were subjected to analysis of variance. Sources of variation were temperature and storage time. Comparison of means was conducted with the Fisher's least significant difference test at a significance level $P=0.05$. Least significant difference values are provided in all figures captions and tables.

\section{RESULTS AND DISCUSSION}

Moisture loss appeared as one of the primary parameters affecting fresh chives quality. Weight loss of trays increased significantly during storage time at both 0 and $4 \mathrm{C}$ (Table 1). In all sampling points, weight loss of trays was significantly higher at $4 \mathrm{C}$ than at $0 \mathrm{C}$. For both assayed temperatures, the linear regression analysis showed a statistically significant relationship between weight loss and storage time. At $0 \mathrm{C}(r=0.999, P<<0.01)$, the weight loss rate was $0.55 \%$ per day, whereas, at $4 \mathrm{C}(r=0.993, P<<0.01)$, the weight loss was $0.87 \%$ per day. Likewise, Tsouvaltzis et al. (2006) found that cut leek (Allium porrum L.) stalks lost fresh weight linearly with storage time at 4C ( $r=0.940$, $P<0.0001$ ) to as much as $2.64 \%$ of initial fresh weight, on day 9 of storage.

Weight loss values registered in our experiments after 14 days of storage were higher than the ones reported by Aharoni et al. (1989) in chives packaged in perforated polyethylene bags and stored for 5 days at $6 \mathrm{C}$ plus 2 days at $12 \mathrm{C}$. 
TABLE 1.

WEIGHT LOSS $(\%)$ OF TRAYS CONTAINING FRESH CHIVES LEAVES STORED AT 0 OR 4C FOR 21 DAYS

\begin{tabular}{lcc}
\hline \multirow{2}{*}{$\begin{array}{l}\text { Time } \\
\text { (days) }\end{array}$} & \multicolumn{2}{l}{ Weight loss (\%) } \\
\cline { 2 - 3 } & $0 \mathrm{C}$ & $4 \mathrm{C}$ \\
\hline 0 & $0.00^{\mathrm{ax}}$ & $0.00^{\mathrm{ax}}$ \\
7 & $3.84^{\mathrm{bx}}$ & $4.70^{\mathrm{by}}$ \\
14 & $7.70^{\mathrm{cx}}$ & $11.75^{\mathrm{cy}}$ \\
21 & $11.79^{\mathrm{dx}}$ & $20.07^{\mathrm{dy}}$ \\
LSD $_{0.05}$ & 0.43 & \\
\hline
\end{tabular}

Values within each column followed by different letters (a-d) and within each row $(\mathrm{x}-\mathrm{y})$ indicate significant differences $(P<0.05)$. LSD, least significant difference.

TABLE 2.

HUE AND $L^{*}$ VALUES OF THE CIE SCALE IN FRESH CHIVES STORED AT 0 OR 4C FOR 21 DAYS

\begin{tabular}{|c|c|c|c|c|}
\hline \multirow{2}{*}{$\begin{array}{l}\text { Time } \\
\text { (days) }\end{array}$} & \multicolumn{2}{|l|}{ Hue } & \multicolumn{2}{|l|}{$L^{*}$} \\
\hline & $O C$ & $4 C$ & $O C$ & $4 \mathrm{C}$ \\
\hline 0 & $135.2^{\text {oax }}$ & $135.2^{\text {oax }}$ & $38.2^{\mathrm{ax}}$ & $38.2^{\text {ax }}$ \\
\hline 7 & $128.2^{\mathrm{obx}}$ & $127.9^{\circ b x}$ & $43.8^{\mathrm{bx}}$ & $43.4^{\mathrm{bx}}$ \\
\hline 14 & $123.2^{\text {ocx }}$ & $114.7^{\text {ody }}$ & $48.1^{\mathrm{cx}}$ & $50.5^{\mathrm{cx}}$ \\
\hline 21 & $114.2^{\text {od }}$ & - & $55.7^{\mathrm{d}}$ & - \\
\hline $\mathrm{LSD}_{0.05}$ & 3.4 & & 2.7 & \\
\hline
\end{tabular}

Values within each column $(\mathrm{a}-\mathrm{d})$ and within each row $(\mathrm{x}-\mathrm{y})$ followed by different letters indicate significant differences $(P<0.05)$.

LSD. least significant difference.

Surface color evolution of fresh chives was characterized by means of the color angle $(h)$ (Table 2 ). After 14 days of storage, $h$ decreased significantly by $9 \%$ and $15 \%$ for samples stored at 0 and $4 \mathrm{C}$, respectively. Samples maintained at $4 \mathrm{C}$ were not marketable at this point because of noticeable yellowing of leaves. After 21 days at $0 \mathrm{C}, h$ reached a value similar to the one found at $4 \mathrm{C}$ after 14 days of storage. Thus, storing chives at $0 \mathrm{C}$ delayed the loss in color by approximately 1 week.

The variation of $L^{*}$ during the storage of fresh chives is shown in Table 2, where a significant increase can be observed for samples stored at both 0 and $4 \mathrm{C}$. At $0 \mathrm{C}$, the increase of $L^{*}$ correlated inversely with the variation in $h$ of refrigerated fresh chives (Pearson's correlation coefficient $=-0.928$ ).

At the beginning of the experiments, the total chlorophyll content of fresh chives was $73 \mathrm{mg} / 100 \mathrm{~g}$ fresh tissue. Kmiecik and Lisiewska (1999) reported 


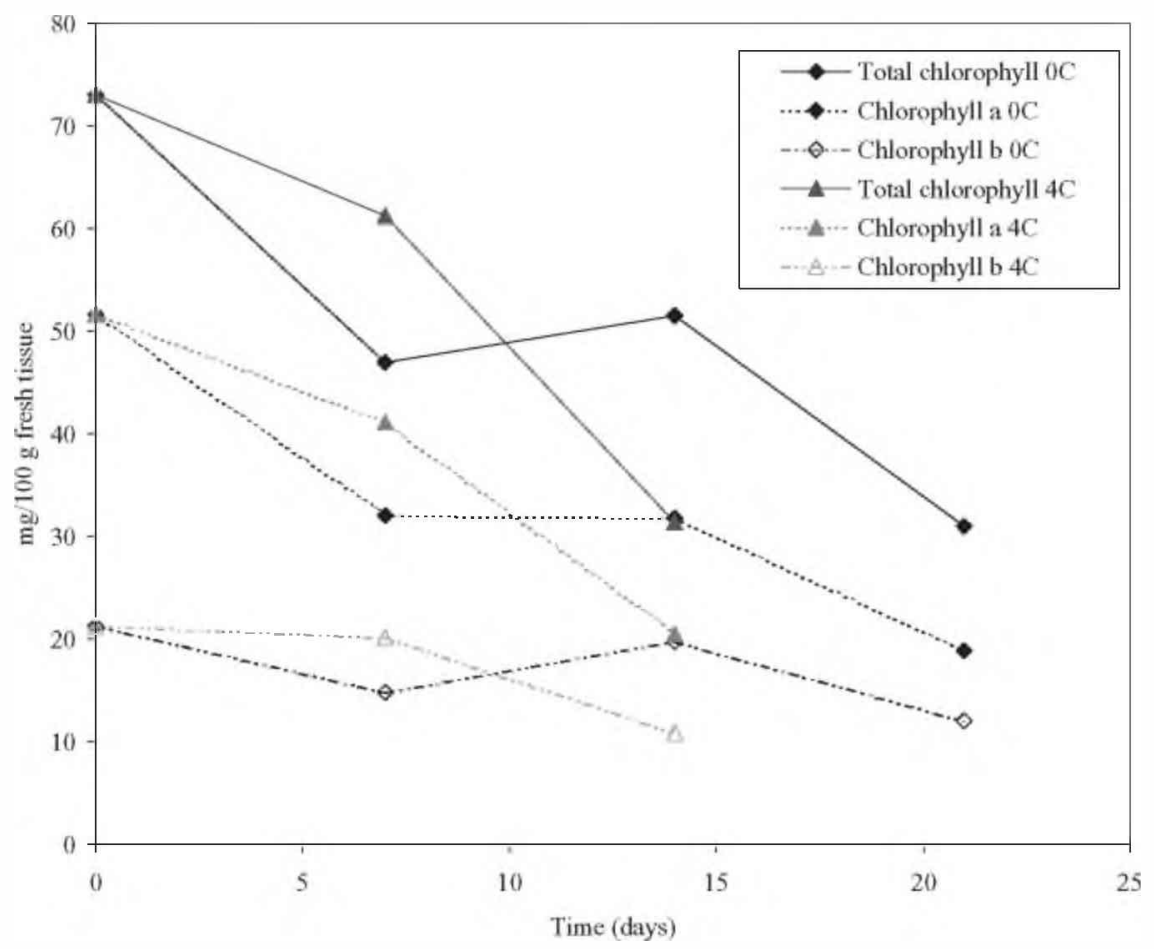

FIG. 1. TOTAL CHLOROPHYLL, CHLOROPHYLL $a$ AND CHLOROPHYLL $b$ CONTENT (mg/100 g FRESH TISSUE) OF CHIVES STORED DURING 21 OR 14 DAYS AT 0 OR 4C. RESPECTIVELY

$\mathrm{LSD}_{0.05}$ total chlorophyll $=5.2 ; \mathrm{LSD}_{0.05}$ chlorophyll $a=5.3 ; \mathrm{LSD}_{0.05}$ chlorophyll $b=1.9$. LSD. least significant difference.

a higher chlorophyll ( $a$ plus $b$ ) content in fresh chive leaves, which corresponded to $121 \mathrm{mg} / 100 \mathrm{~g}$ of fresh matter.

After 21 days at $0 \mathrm{C}$, total chlorophyll levels diminished signilicantly, reaching a value that corresponded to $42 \%$ of the initial one. The evolution of chlorophyll $a$ was very similar to the trend showed by total chlorophyll content, whereas chlorophyll $b$ levels remained constant during 21 days at $0 \mathrm{C}$ (Fig. 1). When samples were kept at $4 \mathrm{C}$, total chlorophyll content decreased by $43 \%$ with respect to the starting level, after 14 days of storage (Fig. 1). Chlorophyll $a$ evolved in the same way as total chlorophyll did. Chlorophyll $b$ remained constant during the first week at $4 \mathrm{C}$ and then diminished signilicantly (day 14). Results indicate that total chlorophyll and chlorophyll $a$ degradation could be delayed approximately by a week by storing samples at $0 \mathrm{C}$. At the beginning of the storage, the ratio between total carotenoids and 
TABLE 3.

TOTAL CAROTENOID CONTENT ( $\mathrm{mg} / 100 \mathrm{~g}$ FRESH TISSUE) OF FRESH CHIVES STORED AT O OR 4C FOR 21 OR 14 DAYS

\begin{tabular}{lll}
\hline \multirow{2}{*}{$\begin{array}{l}\text { Time } \\
\text { days }\end{array}$} & \multicolumn{2}{l}{ Total carotenoid content (mg/100 g fresh tissue) } \\
\cline { 2 - 3 } & $0 \mathrm{C}$ & $4 \mathrm{C}$ \\
\hline 0 & $16.8^{\mathrm{abx}}$ & $16.8^{\mathrm{abx}}$ \\
7 & $14.8^{\mathrm{cx}}$ & $18.4^{\mathrm{ay}}$ \\
14 & $18.7^{\mathrm{ax}}$ & $15.4^{\mathrm{by}}$ \\
21 & $15.6^{\mathrm{bc}}$ & - \\
LSD $_{0.05}$ & 1.9 & \\
\hline
\end{tabular}

Values within each column followed by different letters (a-c) and within each row $(x-y)$ indicate significant differences $(P<0.05)$. LSD. least significant difference.

total chlorophyll content was 0.23 , slightly below the overall stoichiometry of total carotenoid to total chlorophyll ( $a$ plus $b$ ) (Bowyer and Leegod 1997). Total carotenoid content of fresh chives showed slight variations during refrigerated storage (Table 3 ).

Initial reducing sugars content of fresh chives was $3.03 \mathrm{~g}$ glucose $/ 100 \mathrm{~g}$ fresh tissue, which is consistent with the levels reported by Kmiecik and Lisiewska (1999). When samples were maintained at 0C, reducing sugars content decreased up to $46 \%$ of the starting value after 21 days, while samples stored at $4 \mathrm{C}$ lost $48 \%$ of reducing sugars after 14 days of storage (Fig. 2). Hong et al. (2000) reported that soluble sugar concentrations in the white stems bases of green onions (Allium cepa $\times$ Allium fistulosum) decreased by $30 \%$ of the initial content when they were stored at $5 \mathrm{C}$ for 7 days.

Browning potential of fresh chives rose up significantly at both 0 and $4 \mathrm{C}$, after 7 days of storage (Fig. 2). From then on, this parameter remained constant for samples stored at $0 \mathrm{C}$ but continued increasing in samples kept at $4 \mathrm{C}$.

According to the results concerning weight loss, surface color, pigments, reducing sugars and browning potential during the refrigerated storage of fresh chives, the shelf life of the product at OC was set at 14 days. Storing fresh chives at $4 \mathrm{C}$ shortened the shelf life of the product approximately by a week in comparison with the evolution of attributes observed at $0 \mathrm{C}$.

Regarding internal atmosphere composition of samples stored at $0 \mathrm{C}$, Fig. 3 shows that $\mathrm{CO}_{2}$ concentration increased signilicantly on the second day of storage. Then, $\mathrm{CO}_{2}$ levels remained stable up to the end of storage. On the other hand, $\mathrm{O}_{2}$ consumption was not detectable probably because of the high $\mathrm{O}_{2}$ permeability rate of the film used. Figure 3 shows that $\mathrm{O}_{2}$ concentration inside packages remained constant for more than 2 weeks at $0 \mathrm{C}$. Aharoni et al. 


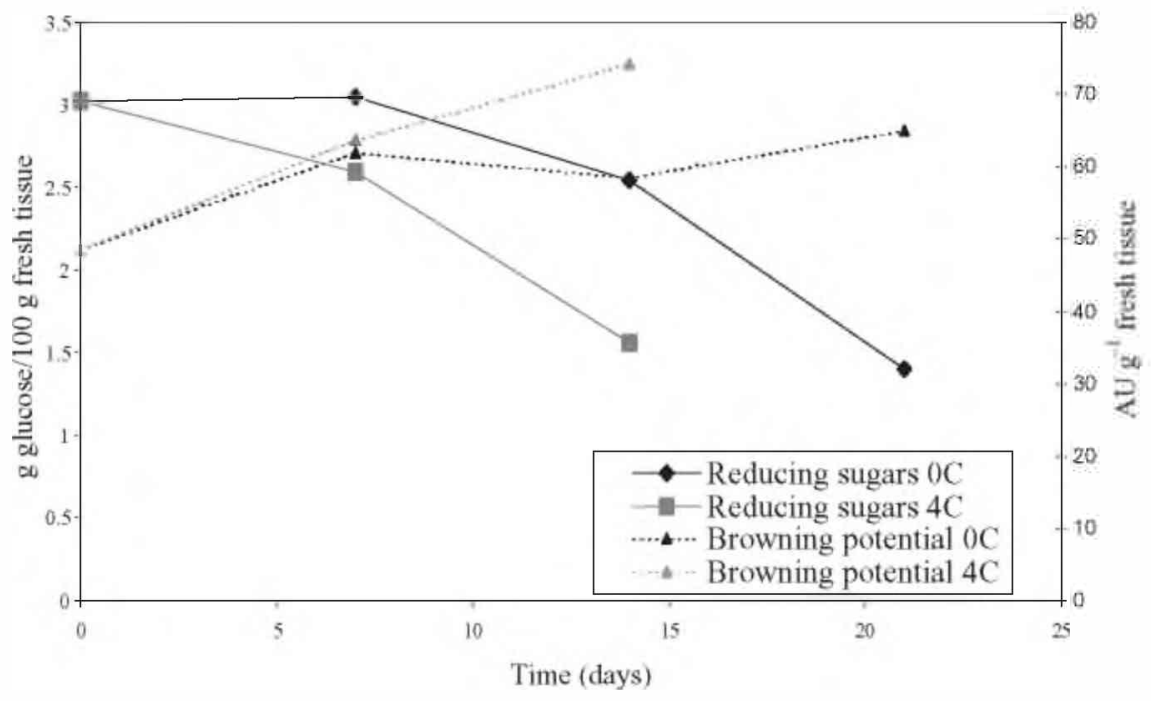

FIG. 2. REDUCING SUGAR CONTENT (g GLUCOSE/100 g FRESH TISSUE) AND BROWNING POTENTIAL (ABSORBANCE UNITS/g FRESH TISSUE) OF CHIVES STORED DURING 21 OR 14 DAYS AT 0 OR 4C. RESPECTIVELY $\mathrm{LSD}_{005}$ reducing sugars $=0.3 ; \mathrm{LSD}_{005}$ browning potential $=8.5$. LSD, least significant difference.

(1988) pointed out that green herbs susceptible to yellowing and decay were well conserved when they were packaged in nonperforated polyethylene liners. This was attributed to the elevation of $\mathrm{CO}_{2}$ concentration (to $1-5 \%$ ) within the packages. In the same way, Aharoni et al. (1989) found that packaging chives in a sealed polyethylene-lined carton allowed to the maximum reduction of yellowing and decay after 5 days at $6 \mathrm{C}$ plus 2 days at $12 \mathrm{C}$. The authors also mentioned that the accumulation of $\mathrm{CO}_{2}(5.7 \%)$ rather than the decrease in $\mathrm{O}_{2}(12 \%)$ inside the packages could have been the reason for the retardation of senescence.

Changes in total phenolics content are shown in Table 4 . The values remained constant up to day 6 , when total phenolics concentration showed a significant increase. At this point, the reached level was $12 \%$ higher than the initial one. At day 13, values did not significantly differ from the initial or from the highest one. Total phenolics content found in chive leaves was intermediate between those reported for other Allium vegetables, such as shallots $(114.7 \mathrm{mg}$ gallic acid equivalents $/ 100 \mathrm{~g}$ of sample $=$ $177.1 \mathrm{mg}$ catechin $/ 100 \mathrm{~g}$ sample) and Vidalia onion $(16.8 \mathrm{mg}$ gallic acid equivalents $/ 100 \mathrm{~g}$ of sample $=25.9 \mathrm{mg}$ catechin $/ 100 \mathrm{~g}$ of sample) (Yang et al. 2004). 


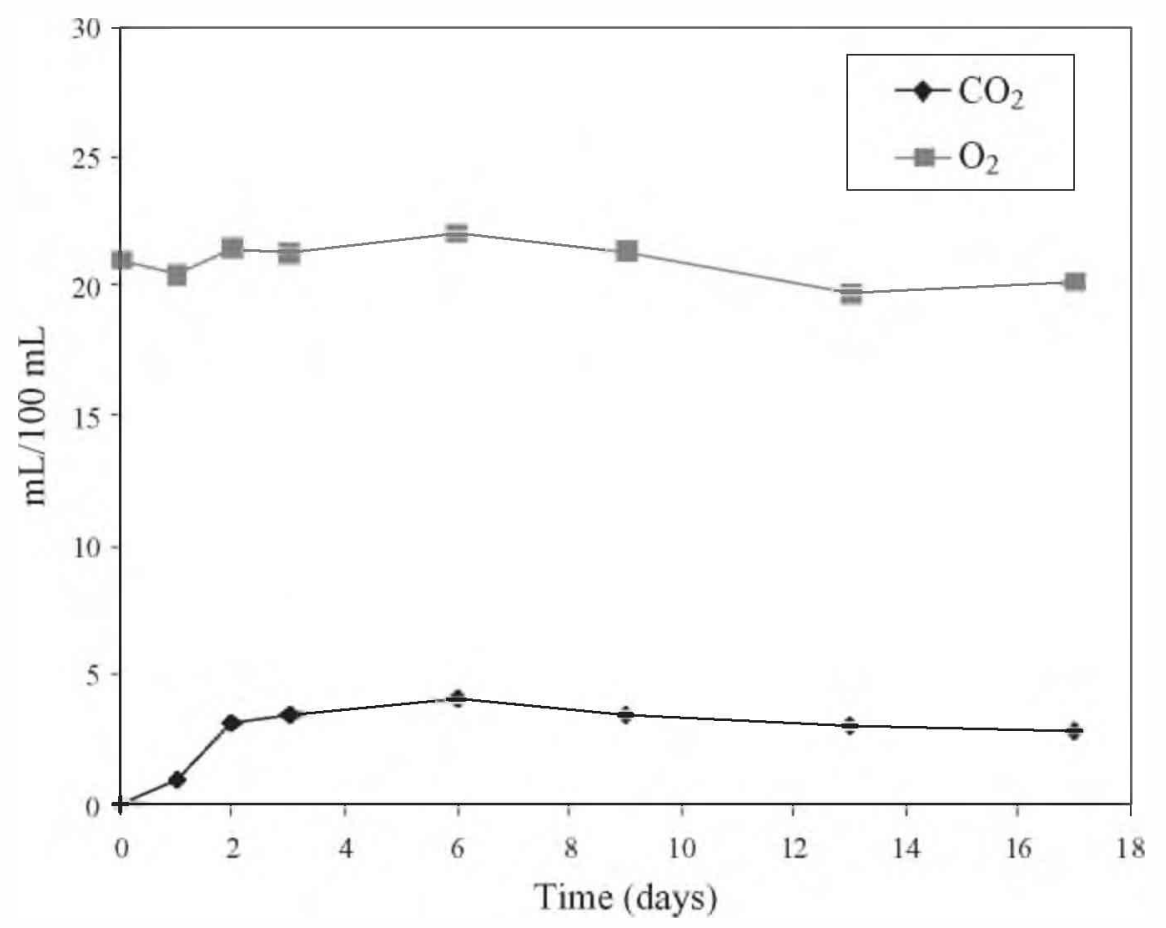

FIG. 3. $\mathrm{CO}_{2} \mathrm{AND} \mathrm{O}_{2}$ CONTENT (mL/100 mL) INSIDE PACKAGES OF FRESH CHIVES STORED AT OC $\mathrm{LSD}_{0.05} \mathrm{CO}_{2}=1.6 ; \mathrm{LSD}_{0.05} \mathrm{O}_{2}=2.3$. LSD, least significant difference.

Initial ascorbic acid content of fresh chives $(18.4 \mathrm{mg} / 100 \mathrm{~g}$ fresh tissue) diminished significantly after 3 days of storage at $0 \mathrm{C}$ (Table 4). From then on, values remained constant up to the end of the assayed period. The total average diminution of ascorbic acid content during 13 days at $0 \mathrm{C}$ represented $30 \%$ with respect to the initial value. Kmiecik and Lisiewska (1999) have reported $133 \mathrm{mg}$ vitamin $\mathrm{C} / 100 \mathrm{~g}$ fresh matter in nonblanched chives, being $96 \%$ of this value the percentage of L-ascorbic acid. Stajner et al. (2004) have mentioned that the content of vitamin $\mathrm{C}$ in the leaves of $A$. schoenoprasum was $0.12 \pm 0.03 \mathrm{mg} / \mathrm{mg}$ protein.

Radical scavenging activity of fresh chives was $327 \mu \mathrm{mol} \mathrm{DPPH} / 100 \mathrm{~g}$ fresh tissue. The values remained constant during the first 3 days and then showed a slight trend to increase between days 6 and 13 of the refrigerated storage (Table 4). Nuutila et al. (2003) have investigated the antioxidant activities of Allium vegetables extracts as well as several chemical components. The 
TABLE 4.

TOTAL PHENOLICS (mg CATECHIN/100 g FRESH TISSUE), ASCORBIC ACID (mg/100 g FRESH TISSUE) AND RSA ( $\mu$ mol DPPH $/ 100 \mathrm{~g}$ FRESH TISSUE) OF FRESH CHIVES STORED AT OC FOR 13 DAYS

\begin{tabular}{|c|c|c|c|}
\hline \multirow{2}{*}{$\begin{array}{l}\text { Time } \\
\text { (days) }\end{array}$} & \multirow{2}{*}{$\begin{array}{l}\text { Total phenols } \\
\text { (mg catechin } / 100 \mathrm{~g} \\
\text { fresh tissue) }\end{array}$} & \multirow{2}{*}{$\begin{array}{l}\text { Ascorbic acid } \\
\text { (mg/100 g } \\
\text { fresh tissue) }\end{array}$} & \multirow{2}{*}{ 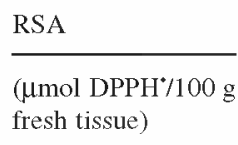 } \\
\hline & & & \\
\hline 0 & $84.4^{1 \mathrm{c}}$ & $18.4^{\mathrm{a}}$ & $327.2^{\mathrm{ab}}$ \\
\hline 3 & $79.1^{c}$ & $11.2^{\mathrm{b}}$ & $278.0^{\mathrm{b}}$ \\
\hline 6 & $94.3^{\mathrm{a}}$ & $12.6^{\mathrm{b}}$ & $360.2^{\mathrm{a}}$ \\
\hline 9 & $84.8^{1 x}$ & $13.2^{\mathrm{b}}$ & $347.1^{\mathrm{a}}$ \\
\hline 13 & $92.3^{\mathrm{ab}}$ & $14.8^{\mathrm{ab}}$ & $396.1^{a}$ \\
\hline $\operatorname{LSD}_{0.05}$ & 9.3 & 4.7 & 77.4 \\
\hline
\end{tabular}

Values within each column followed by different letters indicate significant differences $(P<0.05)$. LSD, least significant difference; RSA, radical scavenging activity.

authors have found kaempferol as a polyphenolic constituent of chives leaves, being one of the compounds contributing to the antioxidant activity of this herb.

\section{CONCLUSIONS}

Results found in this work show that fresh chives' shelf life can be extended by at least a week when they are stored at $0 \mathrm{C}$ as opposed to a temperature of $4 \mathrm{C}$, which is not substantially higher. Weight loss of trays, surface color degradation, green pigments and reducing sugar loss could be delayed and browning potential can be reduced by keeping the product at $0 \mathrm{C}$. As weight loss values were high at both 0 and $4 \mathrm{C}$, other plastic films of lower water vapor permeability rates than polyvinyl chloride film should be assayed in future experiences. The analysis of total phenolics content and radical scavenging activity of samples kept at $\mathrm{OC}$ did not show clear evidence of deleterious changes, even after 13 days of refrigerated storage.

\section{ACKNOWLEDGMENTS}

Laboratory work was carried out with the financial support provided by the Agencia Nacional de Promoción Científica y Tecnológica (Project BID 1728/OC-AR PICTR 126/02, directed by Dr AR Chaves). Authors express 
their gratitude to A. Mugridge and R. Ferreyra for their assistance in the laboratory work and to Ing. Agr. J. A. Ringuelet for the provision of plant material.

\section{REFERENCES}

AHARONI, N., DVIR, O., REUVENI, A., AHARON, Z., GUR, G., NOI, M., TENE, A., KURIS, U. and EFRAT, U. 1988. Film packaging and vacuum precooling of green herbs for export. Hassadeh 68,767-771.

AHARONI, N., REUVENI, A. and DVIR, O. 1989. Modified atmospheres in film packages delay senescence and decay of fresh herbs. Acta Hortic. $258,255-262$.

BIANCHINI, F. and VAINIO, H. 2001. Allium vegetables and organosulfur compounds: Do they help prevent cancer? Environ. Health Perspect. 109(9), 893-902.

BOWYER, J.R. and LEEGOD, R.C. 1997. Photosynthesis. In Plant Biochemistry (P.M. Dey and J.B. Harborne, eds.) pp. 49-110, Academic Press, London.

BRAND-WILLIAMS, W., CUVELIER, M.E. and BERSET, C. 1995. Use of a free radical method to evaluate antioxidant activity. Lebensm. Wiss. Technol. 28, 25-30.

CANTWELL, M. and REID, M. 2006. Herbs: (Fresh Culinary). Recommendations for maintaining postharvest quality. http://postharvest.ucdavis. edu/Produce/ProduceFacts/Veg/herbs.shtml (accessed September 9, 2006).

EGERT, M. and TEVINI, M. 2002. Influence of drought on some physiological parameters symptomatic for oxidative stress in leaves of chives (Allium schoenoprasum). Environ. Exp. Bot. 48, 43-49.

HONG, G., PEISER, G. and CANTWELL, M.I. 2000. Use of controlled atmospheres and heat treatment to maintain quality of intact and minimally processed green onions. Postharvest Biol. Technol. 20, 5361.

KMIECIK, W. and LISIEWSKA, Z. 1999. Effect of pretreatment and conditions and period of storage on some quality indices of frozen chive (Allium schoenoprasum L.) Food Chem. 67, 61-66.

LE BON, A.M. and SIESS, M.H. 2000. Organosulfur compounds from Allium and the chemoprevention of cancer. Drug Metab. Interact. 17(1-4), 51-79.

LICHTENTHALER, H.K. 1987. Chlorophylls and carotenoids: Pigments of photosynthetic biomembranes. Meth. Enzymol. 148, 350-382. 
LOAIZA-VELARDE, J.G., TOMÁS-BARBERÁ, F.A. and SALTVEIT, M.E. 1997. Effect of intensity and duration of heat-shock treatments on woundinduced phenolic metabolism in iceberg lettuce. J. Am. Soc. Hortic. Sci. 122(6), 873-877.

NUUTILA, A.M., PUUPPONEN-PIMIÄ, R., AARNI, M. and OKSMANCALDENTEY, K-M. 2003. Comparison of antioxidant activities of onion and garlic extracts by inhibition of lipid peroxidation and radical scavenging activity. Food Chem. 81, 485-493.

SENGUPTA, A., GHOSH, S. and BHATTACHARJEE, S. 2004. Allium vegetables in cancer prevention: An overview. Asian Pac. J. Cancer Prev. 5(3), 237-245.

SOUTHGATE, D.A.T. 1976. Determination of Food Carbohydrates, pp. 105106, Applied Science Publishers, London.

STTAJNER, D., CANADANOVIĆ-BRUNET, J. and PAVLOVIC, A. 2004. Allium schoenoprasum L., as a natural antioxidant. Phytother. Res. 18, $522-524$.

SWAIN, T. and HILLIS, W.E. 1959. The phenolic constituents of Prunus domestica I. The quantitative analysis of phenolic constituents. J. Sci. Food Agric. 10, 63-68.

TSIAGANIS, M.C., LASKARI, K. and MELISSARI, E. 2006. Fatty acid composition of Allium species lipids. J. Food Comp. Anal. 19(6-7), 620-627.

TSOUVALTZIS, P., SIOMOS, A.S. and GERASOPOULOS, D. 2006. Effect of hot water treatment on leaf extension growth, fresh weight loss and color of stored minimally processed leeks. Postharvest Biol. Technol. 39, $56-60$.

WIMALASIRI, P. and WILLS, R.B.H. 1983. Simultaneous analysis of ascorbic acid and dehydroascorbic acid in fruit and vegetables by highperformance liquid chromatography. J. Chrom. A 256, 368-371.

YANG, J., MEYERS, K.J., VAN DER HEIDE, J. and HAI LIU, R. 2004. Varietal differences in phenolic content and antioxidant and antiproliferative activities of onions. J. Agric. Food Chem. 52, 6787-6793. 